\title{
Pengaruh Percaya Diri Terhadap Ketrampilan Berbicara
}

\author{
Ani Fakhiroh \\ Institut Agama Islam Negeri (IAIN) Syekh Nurjati Cirebon \\ Email: jazlan.naja@yahoo.com \\ Syarif Hidayatullah \\ Institut Agama Islam Negeri (IAIN) Syekh Nurjati Cirebon \\ Email: syahida3006@gmail.com
}

\author{
ملخص \\ الثقة بالنفس ضرورية للغاية في التنشئة الاجتماعية، لأنه بثقة يمكننا أن نتفاعل مع الآخرين، \\ دون أي شك في قدرتنا، الأشخاص الذين لا يثقون يميلون إلى إغلاق أنفسهم للآخرين، فهم \\ يخافون الكلام أو حتى التفكير مع الآخرين. تحدف هذه الدراسة إلى تحديد ما إذا كان هناك \\ تأثير على الثقة في القدرة على الكلام. \\ قامت هذه المقالة على أن الثقة بالنفس لها أثر عظيم في مهارة الكلام أي فيهما العلاقة القوية \\ المرتبطة. وأسند هذا البحث على الكتب التى تتكلم عن الثقة بالنفس ومهارة الكلام. \\ الكلمة الائيسية: علم النفس، الثقة بالنّس، مهارة الكلام
}

\begin{abstract}
Abstrak
Kepercayaan diri sangatlah dibutuhkan dalam bersosialisasi, karena dengan percaya diri kita dapat berinteraksi dengan yang lainnya, tanpa merasa ragu akan kemampuan yang kita miliki, orang yang tidak percaya diri cendrung menutup dirinya terhadap orang lain, mereka takut akan berbicara atau pun berpendapat dengan yang lainnya. Penelitian ini bertujuan untuk mengetahui apakah ada pengaruh kepercayaan diri terhadap kemampuan berbicara.

Artikel ini menegaskan kepercayaan diri memiliki pengaruh terhadap kemampuan berbicara. Keduanya memiliki hubungan keterkaitan yang sangat erat. Kajian ini bersifat kepustakaan, merujuk pada buku-buku yang membahas kepercayaan diri dan kemampuan berbicara.
\end{abstract}

\section{Kata Kunci: Psikologi, Percaya Diri, Ketrampilan Berbicara}

\section{Pendahuluan}

Bahasa sangat penting dalam kehidupan manusia. Tanpa bahasa setiap kegiatan manusia tidak akan berjalan, karena bahasa adalah alat komunikasi yang digunakan oleh sekelompok orang untuk menyampaikan tujuan. Pun dengan ilmu pengetahuan, tidak akan berkembang jika tidak dibahasakan. 
Oleh sebab itu, bahasa dikatakan sebagai jendela dunia karena berbagai pengetahuan dan 1001 peradaban ada dan tercipta karena dibahasakan¹.

Ketrampilan berbahasa memiliki empat komponen, yaitu : a) ketrampilan menyimak, b) ketrampilan berbicara, c) ketrampilan membaca, dan d) ketrampilan menulis. Sebagai ketrampilan yang bersifat aktif, ketrampilan berbicara bukanlah hal yang mudah untuk dikuasai siswa. Penguasaan membutuhkan penguasaan yang intensif, bukan hanya aspek kebahasaannnya akan tetapi juga aspek non kebahasaannya. ${ }^{2}$

Dalam Proses pembelajaran, rasa percaya diri merupakan salah satu faktor internal dari aspek non kebahasaan yang mendukung siswa akan keberhasilan potensi yang dimilikinya. Rasa percaya diri sangat penting untuk ditanamkan kepada setiap siswa, karena rasa percaya diri bisa menyebabkan kegagalan siswa dalam melaksanakan tugas disekolah maupun saat proses belajar disekolah. ${ }^{3}$

Goyahnya percaya diri umunya bersumber pada anggapan tertentu tentang dirinya yang menyebabkan keberanian untuk betindak maupun kurangnya penghargaan terhadap kehebatan-kehebatan diri. Kepercayaan diri dikaitkan dengan kemampuan atau keberanian individu untuk melakukan tindakan-tindakan yang bukan hanya membawa resiko fisik tetapi juga resiko psikologis. Individu- individu tersebut tidak berani untuk berbicara atau tampil didepan umum, malu mengungkapkan ide-idenya dalam suatu rapat, yang semua ini menurut para remaja yang tidak memiliki kepercayaan diri cukup mengundang resiko dan tidak berani untuk mengambil resiko-resiko tersebut. ${ }^{4}$

Beberapa siswa di kelas persiapan pun memiliki permasalahan kepercayaan diri seperti yang sudah dipaparkan diatas, banyak diantara mereka yang cendrung enggan berbicara didepan umun karena rasa tidak percaya diri dan rasa malu dalam mengungkapkan pendapat mereka.

Untuk mendapatkan solusi atas permasalahan tersebut, maka perlu diadakannya analisis faktor-faktor apa sajakah yang menghambat rasa percaya diri siswa tersebut. Oleh karena itu, kajian ini lebih condong menggunakan pendekatan kuntitatif deskriptif jenis korelasional karena pembahasannya akan dipaparkan berupa narasi dan analisisnya diarahkan kepada buku-buku dan tulisan-tulisan yang berkaitan dengan pembahasan.

1 Fitria Rif'atul Azizah, Analisis Pemikiran Ibnu Khaldun Terhadap Direct Method Dalam Pembelajaran Bahasa Asing. (Cirebon: Skripsi IAIN Syekh Nurjati, 2016). Hal. 1.

2 Arini Susana, Meningkatkan Ketrampilan Berbicara Siswa Melalui Strategi Pembelajaran Kooperatif Tipe Think Pire Share. (Jember: Skripsi IAIN Jember, 2013). Hal. 1.

3 Soebahar, "Wawasan Baru", dalam http://umm.ac.id , 11 januari 2002.

4 Hermadi Fajar Arifin, Pengaruh Kepercayaan Diri Terhadap Komunikasi Interpersonal.(Jakarta: Skripsi UIN Syarif Hidayatullah 2011). Hal. 2. 


\section{Pengertian Percaya Diri}

Menurut Carl Rogers, sebelum mengetahui arti dari percaya diri, kita mengawali istilah self yang di dalam psikologi mempunyai dua arti, yaitu sikap dan perasaan seseorang terhadap dirinya sendiri dan suatu keseluruhan psikologis yang menguasai tingkah laku dan penyesuaian diri. ${ }^{5}$ Self yaitu faktor yang mendasar dalam pembentukan kepribadian dan penentu perilaku diri yang meliputi segala kepercayaan, sikap, perasaan dan cita-cita baik yang disadari ataupun tidak disadari individu pada dirinya.

Menurut Symond dalam bukunya yang berjudul The Ego and The Self menyatakan Self sebagai cara-cara bagaimana seseorang bereaksi terhadap dirinya sendiri. Self itu mengandung empat aspek, yaitu: (1). Bagaimana orang mengamati dirinya sendiri, (2) bagaimana orang berpikir tentang dirinya, (3) bagaimana orang menilai dirinya sendiri dan (4) bagaimana orang berusaha dengan berbagai cara untuk menyempurnakan dan mempertahankan diri.

Dalam tindakan-tindakannya tidak terlalu cemas, merasa bebas untuk melakukan hal-hal yang sesuai keinginan atau tanggung jawab sesui dengan perbuatannya, sopan dalam berinteraksi dengan orang lain, memiliki dorongan prestasi serta dapat mengenal kelebihan dan kekurangan diri sendiri.

Kepercayaan diri merupakan suatu sikap atau keyakinan atas kemampuan diri sendiri sehingga Percaya diri adalah kondisi mental atau psikologis diri seseorang yang memberi keyakinan kuat pada dirinya untuk berbuat atau melakukan suatu tindakan. Orang yang tidak percaya dirimemiliki konsep diri yang negatif, kurang percaya pada kemampuannya, karena itu sering menutup diri. ${ }^{6}$

\section{Cara Mendapatkan Percaya Diri}

Percaya pada diri sendiri membangkitkan kekuatan. Dengan bangkitnya kekuatan-kekuatan itu, kepercayaan kepada diri sendri menjadi bertambah. Jadi ada pengaruh timbal baliknya. Percaya kepada diri sendiri bisa dibesarkan, bisa diperhebat kepada orang yang kepercayaannya ada, namun kurang percaya diri.

Seorang penulis terkenal, Grenville Kleiser, mendapat cara bagaimana kita bisa menanam dan menumbuhkan kepercayaan pada diri kita, yakni sebagai berikut:

a. Percayalah akan kemampuan yang dimiliki

b. Percayalah pada keberhasilan di masa depan

c. Bergaulah kepada seseorang yang memiliki rasa percaya diri yang tinggi

d. Percayalah bahawa kebodohan dapat dilenyapkan oleh rasa percaya diri

\footnotetext{
${ }^{5}$ Rogers , "Berani Berbicara di Depan Publik". (Bandung: Nuansa, 2008)hlm. 20

${ }^{6}$ Rini Jesinta .F. Memupuk Rasa Percaya Diri, (Jakarta: PT. Gramedi, 1995), hlm 11
} 
Bahwa rasa percaya diri membuat seseorang berani memandang sesamanya dengan pandangan yang jernih dan jujur, karena dengan rasa percaya diri menimbulkan kesan baik kepada orang lain. ${ }^{7}$

Percaya diri merupakan salah satu variabel psikologi dan dalam proses pembelajaran dalam sekolah perilaku percaya diri perlu tumbuh kembang agar siswa dapat mengikuti proses pembelajaran secara optimal sesuai dengan kemampuan yang dimiliki oleh siswa. Menurut Thalib percaya diri adalah unsur kepribadian yang menerangkan perilaku dan bagaimana mengarahkan perilaku dengan penuh keyakinan untuk menyampaikan kesuksesan. ${ }^{8}$

\section{Ciri-ciri Percaya Diri}

Orang yang memiliki rasa percaya diri terkadang reflek dan tanpa disadari "Leman" menyebutkan ciri-ciri percaya diri yaitu, independent, tanggung jawab, menghargai diri dan usahanya sendiri, tidak mudah frustasi, suka menerima tantangan, emosi hidup namun dalam keadaan stabil, mudah berkomunikasi dan membantu orang lain. Hal seperti itu akan membawakan keberhasilan terhadap individu. ${ }^{9}$

Adapun Ciri-ciri lain percaya diri, antara lain, mencintai dan memahami diri sendiri, memiliki tujuan jelas, cara berfikir positif dan memiliki motivasi tinggi, yaitu motivasi diri yang dapat membuat seseorang berhasil dalam belajar. Jika pada dirinya sendiri ada keinginan belajar, motivasi untuk hasil dalam belajar bersumber pada rasa ingin tahu, prestasi dan rasa kepercayaan yang tinggi, diantaranya jika seseorang memiliki motivasi keberhasilan yang tinggi:

a. Mempunyai kepercayaan dan motivasi dasar untuk mencapai sukses

b. Mempunyai tingkat kebutuhan dan aspirasi

c. Mempunyai tanggung jawab untuk menyelesaikan tugas

d. Ulet atau gigih dalam melaksanakan tugas, punya optimisme dalam memandang masa depan

e. Tidak suka membuang-buang waktu, menetapkan sesuatu sesuai kemampuan

f. Menetapkan hasil kerja yang maksimal dan mau menerima pendapat orang lain ${ }^{10}$

${ }_{7}$ Sumantri Mertodipuro, Cita-cita Saudara Akan Berhasil. (Jakarta: Gunung Jati, 1982). Hal. 109.

8 Thalib Syamsil Bahri, "Hubungan Percaya Diri dan Harga Diri Dengan Kemampuan Bergaul", dalam www.acehinstitute.org. 15 Mei 2009.

9 Martin Leman, "Membangun Rasa Percaya Diri Anak", dalam leman.or.id/anaku/percayadiri.html. 23 Agustus 2000.

${ }^{10}$ Veithzal Rival, "Prestasi Hasil Belajar Peserta Program MM", dalam http://docstoc.com. 12 Oktober 2009. 
Thursan Hakim bukunya yang berjudul "Mengatasi Rasa Tidak Percaya Diri" menyatakan bahwa orang-orang yang mempunyai rasa percaya diri yang tinggi memiliki ciri-ciri sebagai berikut:

a. Selalu bersikap tenang di dalam mengerjakan segala sesuatu.

b. Mempunyai potensi dan kemampuan yang memadai.

c. Mampu menetralisasi ketegangan yang muncul di dalam berbagai situasi.

d. Mampu menyesuaikan diri dan berkomunikasi di berbagai situasi.

e. Memilki kondisi mental dan fisik yang cukup menunjang penampilannya.

f. Memiliki kecerdasan yang cukup.

g. Memiliki keahlian atau keterampilan lain yang menunjang kehidupannya.

h. Memiliki kemampuan bersosialisasi.

i. Memilki latar belakang pendidikan keluarga yang baik.

j. Memilki pengalaman hidup yang menempa mentalnya menjadi kuat dan tahan di dalam menghadapi berbagai cobaan hidup.

k. Selalu bereaksi positif di dalam menghadapi berbagai masalah. ${ }^{11}$

\section{Faktor-faktor Penyebab Kurang Percaya Diri}

Individu yang mengalami kurang rasa percaya diri disebabkan oleh berbagai faktor berikut:

a. Perasaan tidak mampu untuk berbuat baik, dalam segala hal

b. Merasa curiga terhadap orang lain dan memposisikan diri sebagai korban

c. Beranggapan bahwa orang lainlah yang harus berubah

d. Menolak tanggung jawab hidup untuk mengubah diri menjadi lebih baik

e. Tidak percaya bahwa diri sendiri memiliki kelebihan

f. Lingkungan yang kurang memberikan kasih sayang/ penghargaan terutama dalm masa kanak-kanak dan pada masa remaja

g. Lingkungan yang menerapkan kedisiplinan secara otoriter, tidak memberikan kebebasan berfikir,memilih dan berbuat

h. Keinginan untuk mencapai kesempatan dalam segala hal (idealisme yang tidak realistis)

i. Kegagalan/kekecewaan yang berulang kali tanpa diimbangi dengan optimisme yang memadai

j. Sikap orang tua yang memberikan pendapat dan evaluasi negatif terhadap perilaku dan kelemahan anak.

11 Thursan Hakim, Mengatasi Rasa Tidak Percaya Diri. (Jakarta: Puspa Swara, 2002). Hal. 5. 
Berdasarkan faktor penyebab kurang percaya diri yang telah diungkapkan para ahli diatas, dapat disimpulkan faktor penyebab individu kurang percaya diri adalah:

a. Faktor itern

Faktor intern adalah kemampuan individu dalam mengerjakan sesuatu yang mampu dilakukannya, keberhasilan individu untuk mendapat sesuatu yang mampu dilakukan dan dicita-citakan, keinginan dan tekad yang kuat untuk memperoleh sesuatu yang diinginkan dapat terwujud. Faktor intern ini berasal dari individu sendiri bukan dari lingkungan.

b. Faktor Ekstern

Faktor ekstern merupakan faktor yang berasal dari luar diri individu. Lingkungan keluarga, masyarakat dan sosial,dapat menyebabkan individu kurang memiliki percaya diri, lingkungan sosial remaja memberikan pengaruh yang cukup kuat terhadap pembentukan rasa percaya diri. Salah satu lingkungan remaja yang memberikan pengaruh terhadap percaya diri adalah lingkungan teman sebaya. ${ }^{12}$

\section{Karakteristik Percaya Diri}

Liendenfield mengemukakan ada dua jenis percaya diri yaitu percaya diri lahir dan percaya diri batin. Percaya diri lahir memungkinkan diri individu untuk tampil dan berperilaku dengan cara menunjukan pada dunia luar bahwa individu tersebut yakin akan dirinya. Sedangkan percaya diri batin adalah percaya diri yang memberikan seseorang perasaan dan anggapan bahwa individu dalam keadaan baik. Ciri-ciri yang utama yang memiliki kepercayaan diri batin ada empat, yaitu:

a. Cinta diri adalah suatu perasaan perduli derhadap diri sendiri

b. Pemahaman diri adalah suatu perasaan memahami dirinya dengan cara mau menerima segala kritik maupun saran dari orang lain.

c. Memiliki tujuan yang jelas, artinya memiliki suatu pandangan terhadap sesuatu hal yang ingin dicapai.

d. Berfikir positif, yang berarti melihat sesuatu tidak dari satu sisi saja, tetapi melihat dari berbagai sudut pandang, sehingga terbentuklah dari sesuatu yang jelas.

Selain ciri percaya diri diatas, individu yang memiliki percaya diri juga memiliki ciri-ciri percaya diri lahir, yaitu:

a. Ketrampilan komunikasi, maksudnya adalah mampu menjalin komunikasi dengan orang lain yang berasal dari berbagai usia dan latar belakang, tahu dan bagaimana berganti topik, selain itu ia mempunyai kelakuan yang baik dalam komunikasi verbal maupun non-verbal yang

12 Septri Rahayu Purwanti, Mengatasi Masalah Kepercayaan Diri Siswa Melalui Layanan Konseling. (Semarang: Skripsi UIN Walisongo, 2013). Hal. 24-25. 
menunjukan ia memiliki rasa percaya diri, dapat berbicara didepan umum tanpa rasa takut, dan membaca dan memanfaatkan bahasa tubuh orang lain.

b. Ketegasan adalah sikap yang pasti, tentu dan tidak ragu-ragu yang dimiliki seseorang.

c. Penampilan diri, adalah suatu gaya yang diiliki oelh seseorang dalam bermasyarakat yang meliputi gaya bicara, bersikap, bergaya dalam berpenampilan.

d. Pengendalian perasaan, adalah suatu perasaan pengelolaan diri yang dimiliki oleh individu dalam kehidupan sehari-hari. ${ }^{13}$

\section{Pengertian Ketrampilan Berbicara}

Ketrampilan berbicara mempunyai peranan penting dalam proses belajar mengajar. Berbicara adalah kemampuan mengucapkan bunyi-bunyi artikulasi atau kata-kata untuk mengespresikan, menyatakan serta menyampaikan pikiran, gagasan dan perasaan. Dengan demikian berbicara buka hanya sekedar mampu mengucap bunyi-bunyi atau kata-kata, melainkan berbicara merupakan ketrampilan menyampaikan pikiran, gagasan, ide, dan perasaan melalui bahasa lisan kepada orang lain. ${ }^{14}$

Mulgrave menyatakan berbicara adalah suatu alat untuk mengkomunikasikan gagasan-gagasan yang disusun serta dikembangkan sesui dengan kebutuhan-kebutuhan sang pendengar atau penyimak. Berbicara merupakan instrumen yang mengungkapkan gagasannya secara langsung kepada penyimak, hal itu dimaksudkan agar penyimak itu mengerti atau memahami gagasan yang disampaikan oleh pembicara. ${ }^{15}$

Menurut Suhartono Berbicara merupakan bentuk perilaku manusia yang memanfaatkan faktor-faktor fisik, psikologis, neurologis, semantik, dan linguistik. Pertama, faktor fisik yaitu alat ucap untuk menghasilkan bunyi bahasa, seperti kepala, tangan, dan roman muka yang dimanfaatkan dalam berbicara. Kedua, faktor psikologis dapat mempengaruhi terhadap kelancaran berbicara. Oleh karena itu stabilitas emosi tidak hanya berpengaruh terhadap kualitas suara tetapi juga berpengaruh terhadap keruntutan bahan pembicaraan.Ketiga, faktor neurologis yaitu jaringan saraf yang menghubungkan otak kecil dengan mulut, telinga dan organ tubuh lain yang ikut dalam aktivitas berbicara. Keempat, faktor semantik yang berhubungan

${ }^{13}$ Bayu Febrianto, Ika Herani, dan Yoyon Supriyono, Hubungan Kepercayaan Diri Dengan Kemampuan Interpersonal. (Malang: Program Studi Psikologi Fakultas Ilmu Sosial dan Ilmu Politik Universitas Brawijaya). Hal. 4-5.

14 Tarigan, Berbicara Sebagai Ketrampilan Suatu Bahasa. (Bandung: Angkasa, 1981). Hal. 151.

15 Septiana "Ketrampilan Berbicara" http://septimartiana.blogspot.co.id/2014/01/artikel-keterampilan-berbicara.html diakses pada tanggal 05 Januari 2015. 
dengan makna. Kelima, faktor linguistik yang berkaitan dengan struktur bahasa. Bunyi yang dihasilkan harus disusun menurut aturan tertentu agar bermakna. Jika kata-kata yang disusun itu tidak mengikuti aturan bahasa akan berpengaruh terhadap pemahaman makna oleh lawan bicaranya. ${ }^{16}$

\section{Tujuan Berbicara}

Tujuan utama dari berbicara adalah untuk berkomunikasi. Agar dapat menyampaikan pikiran secara efektif, maka seyogyanyalah pembicara memahami makna segala sesuatu yang ingin disampaikan, pembicara harus mengevaluasi efek komunikasinya terhadappara pendengarnya.

Tujuan umum berbicara menurut Djago Tarigan (1990:149) terdapat lima golongan berikut ini.

a. Menghibur

Berbicara untuk menghibur berarti pembicara menarik perhatian pendengar dengan berbagai cara, seperti humor, spontanitas, menggairahkan, kisah-kisah jenaka, petualangan, dan sebagainya untuk menimbulkan suasana gembira pada pendengarnya.

b. Menginformasikan

Berbicara untuk tujuan menginformasikan, untuk melaporkan, dilaksanakan bila seseorang ingin: a. menjelaskan suatu proses; b. menguraikan, menafsirkan, atau menginterpretasikan sesuatu hal; c. memberi, menyebarkan, atau menanamkan pengetahuan; d. menjelaskan kaitan.

Menurut Tarigan (1981:27), tujuan orang berbicara adalah: (1) melaporkan, (2) menghibur, (3) meyakinkan, dan (4) merundingkan.

c. Menstimulasi

Berbicara untuk menstimulasi pendengar jauh lebih kompleks dari tujuan berbicara lainnya, sebab berbicara itu harus pintar merayu, mempengaruhi, atau meyakinkan pendengarnya. Ini dapat tercapai jika pembicara benar-benar mengetahui kemauan, minat, inspirasi, kebutuhan, dan cita-cita pendengarnya.

d. Menggerakkan

Dalam berbicara untuk menggerakkan diperlukan pembicara yang berwibawa, panutan atau tokoh idola masyarakat. Melalui kepintarannya dalam berbicara, kecakapan memanfaatkan situasi, ditambah

16 Suhartono, Pengembangan Keterampilan Bicara Anak Usia Dini. (Jakarta: Departemen Pendidikan Nasional, Direktorat Jenderan Pendidikan Tinggi, Direktorat Pembinaan Pendidikan Tenaga Kependidikan dan Ketenagaan Perguruan Tinggi, 2005). Hal. 20. 
penguasaannya terhadap ilmu jiwa massa, pembicara dapat menggerakkan pendengarnya. ${ }^{17}$

Berbicara untuk melaporkan, untuk memberikan informasi, atau dalam bahasa inggris disebut informative speaking sering digunakan dalam kehidupan sehari -hari seperti memberi atau menanamkan pengetahuan, menetapkan atau menentukan hubungan antara bendabenda, menerangkan atau menjelaskan suatu proses, dan menginterpretasikan atau menafsirkan sesuatu persetujuan atau pun menguraikan sesuatu tulisan secara lisan.

Cara yang paling umum menjamin serta memadukan suatu perasaan dan menciptakan suasana santai adalah melalui pembicaraan-pembicaraan hiburan. Menghibur adalah membuat orang tertawa dengan hal-hal yang dapat menyenangkan hati. Tidak semua orang yang mempunyai kemampuan berbicara dapat menghibur orang yang diajak bicara atau orang yang mendengarkan pembicaraannya.

Tujuan lain dari aktifitas berbicara adalah untuk meyakinkan, persuasi atau meyakinkan merupakan tujuan kalau pembicara menginginkan tindakan. Dengan demikian pembicara berharap agar apa yang disampaikan dapat diikuti oleh pendengar dengan cara meyakinkan pendengar dengan isi pembicaraanya.

Tujuan yang terakhir orang berbicara adalah berbicara untuk merunding. Pada dasarnya berbicara untuk merunding bertujuan untuk membuat sejumlah keputusan dan rencana. Biasanya berbicara untuk merundingkan terjadi jika seseorang dalam masalah atau dalam suatu pilihan antara benar dan tidak.

Dari uraian di atas dapat disimpulkn bahwa tujuan berbicara adalah untuk melaporkan, menghibur, meyakinkan dan merunding. Oleh sebab itu, berbicara mempunyai peranan penting dalam kehidupan sehari-hari.

\section{Faktor-faktor Penunjang Keterampilan Berbicara}

Berbicara di depan umum memerlukan teknik-teknik tertentu. Penguasaan teknik yang digunakan untuk menyajikan pikiran dan gagasan merupakan persyaratan yang harus dipenuhi oleh calon pembicara. Beberapa syarat yang dimaksud dalah sebagai berikut :

a. Memiliki Keberanian dan Tekad yang Kuat

Keberanian merupakan hal yang sangat mendasar. Tanpa keberanian atau keberanian yang setengah-setengah akan megakibatkan kacaunya pembicaraan. Hal lain yang perlu dimiliki pembicara adalah

17 Deni Iskandar, "Materi Berbicara” http:/file.upi.edu/Direktori/FPBS/ JUR._PEND._BHS._DAN_SASTRA_INDONESIA/196606291991031-DENNYISKANDAR/ MATE, diakses pada 10 September 2015. 
keyakinan atau tekad yang kuat. Tekad yang kuat akan menghilangkan keraguan dan menambah kepercayaan terhadap diri sendiri.

b. Memiliki Pengetahuan yang Luas

Seorang pembicara harus menguasai materi yang akan dibicarakan sehingga dapat menyampaikan gagasan-gagasan secara lancar dan teratur.

c. Memahami Proses Komunikasi Massa

Untuk memahami proses komunikasi massa, pembicara dapat mengawali dengan analisis pendengar dan situasi yang akan membantu pembicara agar dapat bereaksi dengan cepat dan tepat.

d.Menguasai Bahasa yang Baik dan Lancar

Jika pembicara menguasai bahasa dengan baik dan lancar, otomatis akan mempunyai perbendaharaan kosakata yang memadai dengan kosakata yang memadai, pembicara akan mampu berimprovisasi dengan baik pula. Tanpa bahasa yang baik dan lancar, seseorang akan gagal berbicara karena bahasa yang kacau dan tidak mampu mewakili gagasangagasan akan mengganggu penyampaian pesan dalam pidato. Penguasaan bahasa tersebut termasuk lafal, singkatan, istilah, dan sebagainya.

e. Pelatihan yang Memadai

Pelatihan merupakan syarat yang mutlak dalam berbicara di muka umum, khususnya untuk para pemula. Pelatihan yang memadai akan semakin meninggikan nilai pembicaraan karena secara umum dapat disimpulkan bahwa sesuatu yang terencana menghasilkan kualitas yang lebih baik. ${ }^{18}$

\section{Gangguan dalam Berbicara}

Berbicara selalu dipakai dalam semua kegiatan dan profesi, untuk itu diperlukan latihan yang rutin dalam setiap kesempatan. Meskipun kebiasaan berbicara terus dilatih untuk mendapatkan hasil yang baik, masih saja ada kesalahan dalam setiap berbicara.

Gangguan-gangguan yang sering muncul ketika akan dan selama berbicara di depan publik sebagai berikut.

a. Gejala Fisik

Ketika akan berbicara gangguan fisik akan dirasakan pada setiap orang, bentuk

gangguan dirasakan berbeda pada setiap orang sesuai dengan tingkat aktivitas berbicaranya. Gejala fisik tersebut seperti; a) detak jantung semakin cepat, b) lutut gemetar sehingga sulit berdiri, c) suara yang

18

$$
\text { Dewi }
$$

Istikhomah,

"Ketrampilan

Berbicara"

http://dewiistikhomah.blogspot.co.id/2014/01/keterampilan-berbicara_10.html, diakses pada tanggal 10 Januari 2014 
bergetar, seringkali dengan mengejang otot tenggorokan, d) gelombang hawa panas dan seperti mau pingsan, e) kejang perut disertai rasa mual, f) hyperventilasiatau kesulitan bernafas, g) mata berair atau hidung berlendir.

b. Gejala Mental

Yang termasuk dalam kategori proses mental dalam berbicara selama pembicara

tampil, antara lain; a) mengulang kata, kalimat, atau pesan, b) hilang ingatan untuk mengingat fakta dan angka secara cepat, dan c) tersumbatnya pikiran sehingga pembicara tidak tahu apa yang harus diucapkan selanjutnya.

c. Gejala Fisik dan Mental

Gejala fisik dan mental biasanya disertai atau diawali dengan gejala emosional, seperti; a) rasa takut yang berlebihan yang bisa muncul sebelum tampil, b) rasa tidak mampu dan rasa kehilangan kendali, c) rasa tidak percaya diri, seperti seorang anak yang tidak mampu mengatasi masalah, d) panik, e) dan rasa malu

seperti merasa dipermalukan saat presentasi berakhir.

Ketiga kelompok gejala di atas bisa saling berinteraksi, rasa ngeri yang muncul saat menunggu giliran untuk berbicara kemudian mengganggu konsentrasi yang menyebabkan kesulitan dalam berbicara selanjutnya. Gangguan-gangguan tersebut akan menghilang bersamaan dengan kesempatan berbicara yang intensif dan latihan yang terus menerus dengan terus memperbaiki gangguan tersebut. ${ }^{19}$

\section{Bentuk-Bentuk Berbicara}

Kegiatan berbicara memiliki beberapa bentuk seperti berbicara dalam diskusi,panel, seminar, moderator, seni drama, wawancara, memandu acara, bercerita, pemberitaan, telepon-menelepon, rapat, ceramah, dan berpidato. Bentuk berbicara meliputi presentasi, seminar, wawancara, moderator, pemandu acara (MC), dan berpidato.

Bentuk berbicara terdiri dari diskusi, bermain peran, moderator, wawancara, berpidato, dan lain-lain, ini semua bisa dikemas dengan cantik melalui modelmodel dalam proses pembelajaran yang diapresiasikan secara berbeda seperti talk show oleh peserta didik sehingga pembelajaran menjadi lebih menarik minat belajar.

Dapat dikatakan bentuk berbicara dapat terjadi dalam berbagai hal dan kesempatan yang terjadi dalam proses komunikasi antar dua orang atau lebih termasuk di dalamnya adalah keterampilan berbicara melalui gelar wicara yang akan dipakai penulis untuk meningkatkan keterampilan berbicara siswa dalam

${ }^{19}$ Rogers Natalie, Berani Berbicara di Depan Publik. (Bandung: Nuansa, 2008). Hal. 20. 
proses pembelajaran. Alasannya, karena di dalam gelar wicara ada empat unsur pembelajaran, yaitu wawancara, diskusi, moderator, dan memandu acara (pewara). Dari keempatnya dapat dilakukan dengan berbagi peran dalam satu kesempatan berdiskusi yang dilaksanakan dengan cara yang berbeda. ${ }^{20}$

\section{Kesimpulan}

Kepercayaan diri merupakan suatu sikap atau keyakinan atas kemampuan diri sendiri sehingga Percaya diri adalah kondisi mental atau psikologis diri seseorang yang memberi keyakinan kuat pada dirinya untuk berbuat atau melakukan suatu tindakan. Orang yang tidak percaya dirimemiliki konsep diri yang negatif, kurang percaya pada kemampuannya, karena itu sering menutup diri. Adapun faktor penyebab individu kurang percaya diri adalah: a) Faktor intern Faktor intern adalah kemampuan individu dalam mengerjakan sesuatu yang mampu dilakukannya, keberhasilan individu untuk mendapat sesuatu yang mampu dilakukan dan dicita-citakan, keinginan dan tekad yang kuat untuk memperoleh sesuatu yang diinginkan dapat terwujud. Faktor intern ini berasal dari individu sendiri bukan dari lingkungan, b) Faktor Ekstern, faktor ekstern merupakan faktor yang berasal dari luar diri individu. Lingkungan keluarga, masyarakat dan sosial,dapat menyebabkan individu kurang memiliki percaya diri, lingkungan sosial remaja memberikan pengaruh yang cukup kuat terhadap pembentukan rasa percaya diri. Salah satu lingkungan remaja yang memberikan pengaruh terhadap percaya diri adalah lingkungan teman sebaya.

Sedangkan kemampuan berbicara adalah suatu alat untuk mengkomunikasikan gagasan-gagasan yang disusun serta dikembangkan sesui dengan kebutuhan-kebutuhan sang pendengar atau penyimak. Berbicara merupakan instrumen yang mengungkapkan gagasannya secara langsung kepada penyimak, hal itu dimaksudkan agar penyimak itu mengerti atau memahami gagasan yang disampaikan oleh pembicara. Ketrampilan berbicara juga memiliki tujuan yaitu untuk berkomunikasi. Agar dapat menyampaikan pikiran secara efektif, maka seyogyanyalah pembicara memahami makna segala sesuatu yang ingin disampaikan, pembicara harus mengevaluasi efek komunikasinya terhadap para pendengarnya.

20 Dimas Yudistira, "Upaya Meningkatkan Ketrampilan Berbicara menggunakan Model Juni 2012. 


\section{Daftar Pustaka}

Arifin, Hermadi Fajar. 2011. Pengaruh Kepercayaan Diri Terhadap Komunikasi Interpersonal. Jakarta: Skripsi UIN Syarif Hidayatullah.

Azizah, Fitria Rif'atul. 2016. Analisis Pemikiran Ibnu Khaldun Terhadap Direct Method Dalam Pembelajaran Bahasa Asing. Cirebon: Skripsi IAIN Syekh Nurjati.

F, Rini Jesinta. 1995. Memupuk Rasa Percaya Diri. Jakarta: PT. Gramedia.

Febrianto, Bayu. Ika Herani, dan Yoyon Supriyono. Hubungan Kepercayaan Diri Dengan Kemampuan Interpersonal. Malang: Program Studi Psikologi Fakultas Ilmu Sosial dan Ilmu Politik Universitas Brawijaya.

Hakim, Thursan. 2002. Mengatasi Rasa Tidak Percaya Diri. Jakarta: Puspa Swara.

Mertodipuro, Sumantri. 1982. Cita-cita Saudara Akan Berhasil. Jakarta: Gunung Jati.

Natalie, Rogers. 2008. Berani Berbicara di Depan Publik. Bandung: Nuansa.

Purwanti, Septri Rahayu. 2013. Mengatasi Masalah Kepercayaan Diri Siswa Melalui Layanan Konseling. Semarang: Skripsi UIN Walisongo.

Rogers. 2008. Berani Berbicara di Depan Publik. Bandung: Nuansa.

Suhartono. 2005. Pengembangan Keterampilan Bicara Anak Usia Dini. Jakarta: Departemen Pendidikan Nasional, Direktorat Jenderan Pendidikan Tinggi, Direktorat Pembinaan Pendidikan Tenaga Kependidikan dan Ketenagaan Perguruan Tinggi.

Susana, Arini. 2013. Meningkatkan Ketrampilan Berbicara Siswa Melalui Strategi Pembelajaran Kooperatif Tipe Think Pire Share. Jember: Skripsi IAIN Jember.

Tarigan. 1981. Berbicara Sebagai Ketrampilan Suatu Bahasa. Bandung: Angkasa.

http://docstoc.com

http://eprints.uny.ac.id

http://file.upi.edu

http://leman.or.id

http://umm.ac.id

www.acehinstitute.org 